\title{
Reimagining Rural Crime in England: A Historical Perspective
}

Kreseda Smith

Doctoral Researcher

Harper Adams University

Edgmond, Newport

Shropshire, TF10 8NB, UK

Richard Byrne

Senior Lecturer

Harper Adams University

Edgmond, Newport

Shropshire, TF10 8NB, UK

Contact Author - Kreseda Smith: kresedasmith@harper-adams.ac.uk; +44 (0)1952 815113

\begin{abstract}
Rural England is still perceived by many as a crime-free idyll, despite increasing evidence to the contrary. This paper provides a brief history of the emergence of rural crime as we currently understand it, from the dissolution of the monasteries under King Henry VIII (15361540), through to the early twentieth century. Some of the persistent myths surrounding rural crime that are particularly relevant to England will also be considered. This review shows that, despite being seen as a recent issue, rural crime in England has a long and chequered past. As a result, such misunderstandings may have led to the persistence of the myths surrounding rural crime, which means that the problems faced by rural communities continue unabated. By addressing these myths, whilst rural crime is not a recent issue, it has evolved into a modern phenomenon. This paper aims to show that rural crime research as a distinct academic field in England is a necessity.
\end{abstract}

Keywords: rural crime, history of England, gemeinschaft, rural myths, social organisation 


\section{Introduction}

Rural crime is "a subject that rouses strong feelings in many country folk who feel sidelined by police forces that concentrate on urban areas" (Daelnet, 2007). However, despite the increasing issues faced by rural communities, the focus of policing, policy and academic research continues to be urban-centric (Harkness, Harris \& Baker, 2015; Mawby, 2004; Wooff, 2015), and the public continues to view the English countryside as the rural idyll of by-gone eras (Dingwall \& Moody, 1999).

The idealised image of rural crime has historically leaned towards the image of the gentleman poacher (Quinn, 2015), or the idea of the lone rustler taking a sheep or two during the night because he and his family were starving (Main, 2001). The modern reality tends to show a rather different picture, with rural communities experiencing increasing numbers of crimes that are historically considered to be urban crimes, such as drugs production, trafficking and abuse (Herz, 2000; O’Dea et al, 1997), fraud (Mothershaw, 2013; Bourn, 2002) and human exploitation (Talbot, 2011; Newton et al, 2008; Byrne \& Smith, 2016). However, it is interesting to note that the idealised image has some grounds in the truth.

This paper will address the historical development of rural crime as we recognise it today from its roots in the early modern period of English history, through to the early twentieth century. It is argued that, by better understanding the roots of rural crime, it is easier to understand and dispel the myths and falsehoods around rural crime that continue into the present. Furthermore, by understanding how rural crime has developed throughout the centuries, and how it has been influenced by the socio-political climate at various points in English history, researchers, police and policy makers are better equipped to understand rural crime today, how it effects the rural population of England, and, potentially, how it can best be addressed in a contemporary context.

\section{A Brief History of Rural Crime in England}

Historically, society has allowed the myth of the crime-free rural idyll to persist (Mingay, 1989). However, this is far from the truth (Marshall \& Johnson, 2005). This section will provide a brief overview of the evidence of rural crime from the early modern period to the twentieth century. Whilst it may be that similar patterns can be seen in other countries, this review focuses on England.

Rural crime in England was generally attributed to four causes: vagabonds and rootless criminals; the influence of the towns on crimes, such as public disorder due to drunkenness; contested crimes; and labour or political unrest. These are briefly dealt with in turn below.

Williams Chambliss (1964) provides a succinct overview of the development of the vagrancy laws in England. The key aspects are included in the timeline below. References to statutes relate to those detailed in Burns (1764), as directed by Chambliss. 
Table 1: Overview of vagrancy law development in England (Adapted from Chambliss, 1964)

\begin{tabular}{|c|c|c|}
\hline Date & Details & Aim of Statute \\
\hline 1274 & $\begin{array}{l}\text { Statute (3 Ed. } 1 \text { c.1) provides } \\
\text { that religious houses would no longer } \\
\text { be required to provide food and shelter } \\
\text { to travellers }\end{array}$ & $\begin{array}{l}\text { To reduce the financial burden } \\
\text { on religious establishments }\end{array}$ \\
\hline \multicolumn{3}{|c|}{ Black Death c.1348 } \\
\hline 1349 & $\begin{array}{l}\text { First vagrancy statute (35 Ed. } 1 \\
\text { c.1) making it a crime to give alms to } \\
\text { anyone who was unemployed but } \\
\text { capable of working. Refusing to work } \\
\text { led to imprisonment until prepared to } \\
\text { work. By } 1351 \text { ( } 25 \mathrm{Ed} \text {. 3), it was also } \\
\text { stipulated that a person may not leave } \\
\text { town to work elsewhere if there was } \\
\text { available work in their home town }\end{array}$ & $\begin{array}{l}\text { The reduction of movement of } \\
\text { labour, and provide a pool of cheap } \\
\text { labour to landowners when the } \\
\text { numbers of labourers was severely } \\
\text { depleted following the Black Death. } \\
\text { This situation was seen "by the } \\
\text { lawmakers as undesirable” (p.70) }\end{array}$ \\
\hline \multicolumn{3}{|c|}{ Little change, other than increases in punishment until: } \\
\hline 1530 & $\begin{array}{l}\text { Heralded a shift from vagrancy } \\
\text { laws as a way to control labour to a } \\
\text { concern about criminal activities } \\
\text { (p.71) with stratified punishment for } \\
\text { repeat offenders ( } 22 \text { H. } 8 \text { c.12) }\end{array}$ & $\begin{array}{l}\quad \text { Addressing a shift in social } \\
\text { attitudes towards vagrants. No longer } \\
\text { seen as homeless and workshy, now } \\
\text { considered as criminals. }\end{array}$ \\
\hline 1535 & $\begin{array}{l}\text { Repeat offenders of vagrancy } \\
\text { now treated as felons. As a result of } \\
\text { issues with transportation due to } \\
\text { political instability, these people were } \\
\text { sentenced to death under Henry VIII } \\
\text { as an 'enemy of the commonwealth' } \\
\text { ( } 27 \text { H. } 8 \text { c. } 25 \text { ). }\end{array}$ & $\begin{array}{l}\text { To control those who would } \\
\text { prey on merchants/commercial } \\
\text { traders - particularly foreign traders } \\
\text { - who were vital to England's } \\
\text { continued prosperity at the time. }\end{array}$ \\
\hline
\end{tabular}

The dissolution of the monasteries (1536-1540) led to the transfer of vast amounts of monastic and other land from the church to secular landlords (Bernard, 2011). As a result, the landlords of these newly acquired lands started to increase the price of rents paid by their new tenant farmers. This led to the start of a period of concern for the landless labourers who relied on these tenant farmers for employment. With the farmers being made to pay higher rents, they were unable to continue to employ as many labourers, and many of the landless found themselves unemployed without the skills needed to find other gainful employment. In a short period of time, thousands of agricultural labourers found themselves without work and resorting to desperate measures to survive. Although the term 'criminal' was not used as a noun until 1626, and 'crime' as an abstract concept was not widely used until the early nineteenth century (Briggs, Harrison, McInnes and Vincent, 1996: 19), as the numbers of unemployed labourers increased over time, a moral panic ensued, with these 'vagabonds' 
soon becoming the archetypal early modern rootless criminals, described in the Vagabonds and Beggars Act 1495 as “idle and suspected persons living suspiciously” (Tomlins \& Raithby, 1811: 763).

The rise in numbers of homeless poor in the seventeenth century was attributable to a combination of two socioeconomic issues. The first of these issues is massive population increase, which is indicated by the doubling of the population in England between 1500 and 1630 (Sharpe, 1984). The second contributing factor was the constant fluctuation of the harvest. Poor weather meant that often there was not enough work to go around, both in the towns and the countryside (Coleman, 1956). Whilst not all homeless poor people were criminals, there was a persistent community of criminal vagabonds who were seen as master malefactors (Matsuda, 1996: p. 124) whose actions succeeded in perpetuating the moral panic that had arisen around such rootless criminals (Kinney, 1990).

During the Early Modern period (1500-1800), the overwhelming majority of crime experiences was petty crimes (Sharpe, 1996), seen in the form of brawling, petty theft and drunkenness, and found mostly in towns and cities of the time. This period also saw the rise of 'socio-political' crime (Briggs et al, 1996: 87) which, by definition, affected the lower classes of society, and so it follows that those most affected were the people who lived and worked in the English countryside. Such activities tended only to be seen as criminal by certain sections of the community, generally the landed classes, whilst for rural dwellers, such as poor cottagers and craftsmen, they were simply continuing traditions handed down generation to generation, and therefore arose as contested crimes between the different classes of society. Three types of crime are identified as falling within this classification:

i. Long-term crimes were those offences that were seen as illegal throughout the period. The main example of such crime in the countryside was poaching, which was to be found in almost all parts of England. Surprisingly, poaching was not restricted to the poorer sections of society, as it was often the case that substantial numbers of farmers as well as cottagers and labourers could be found amongst convicted poachers (Jones, 1979; Hopkins, 1985).

ii. Those customs and traditional practices that were criminalised during the early modern period, such as wood theft. Wood rights were a particular concern of peasant sand rural labourer as they would gather fallen branches as well as small branches that could be easily broken off by hand for fuel, fencing and house repairs. By 1766 a statute was enforced that "aimed to remove all possible equivocation and establish firmly the criminality of wood gathering” (Bushaway, 1981). This led to rural inhabitants being increasingly branded as criminals and subjected to summary trial and conviction. Because of this, by 1800 wood theft was the single most prevalent crime committed in the countryside (Briggs et al, 1996: 92). 
iii. In some cases, actions that would have been considered as criminal by most men and women, sometimes led to the perpetrators being viewed with more sympathy, and even given acclaim for their actions when the same circumstances affected other people. Acts such as assault, threats of violence, the killing of livestock, arson, the tearing down of fences and hedgerows or breaking and entering often fell into this category of circumstantial crimes. One example of this was the process of enclosure; the breaking up of the open farmland surrounding English villages into smaller enclosures that were privately farmed and managed. In many cases, enclosures in English counties were agreed without much protest, however sometimes trouble and opposition arose, particularly when enclosure was accompanied with a change from arable to pasture farming. This resulted in jobs often being lost as livestock farming was less labour intensive than the growing of crops, leading to normally law-abiding citizens reacting by way of protest and tearing up the newly planted fences and hedges.

Despite the attempts to combat poaching during the early modern period, this offence continued into the nineteenth century and beyond. This rise was due in part to the proliferation of criminal gangs of poachers and sheep stealers who continued to ply their trade, not because they needed to in order to survive, but because they had established a criminal business out of stealing to supply a ready market of urban game and poultry dealers, innkeepers, and victuallers (Emsley, 1987; McLynn, 1989). It is interesting to note that, in many cases, judges, juries and even prosecutors were seen to provide some leniency to those defendants who were before the court accused of theft that would normally result in the death penalty being passed, and was noticeable in cases relating to the theft of livestock.

Throughout the early modern period, and into the nineteenth century, the number of crimes punishable by death grew inextricably, and included theft of property (Briggs et al, 1996). It is the traditional distinction between petty and grand larceny that is key to the ability for authorities and juries to grant leniency to the accused (Sharpe, 1984). Traditionally, any theft of goods totalling less than a shilling was classed as petty larceny, and attracted punishments, such as whipping. Any theft of goods that totalled more than a shilling, is classed as grand larceny, and was punishable by death. However, in practice, juries would often find the defendant guilty of a lesser crime than that which he was originally charged. This would be done either by a jury finding a defendant guilty of only one out of several charges, or by the jury deliberatively undervaluing the goods that had been stolen (Briggs et al, 1996). This resulted in the defendant being convicted of the lesser crime of petty larceny, and therefore escaping the death penalty.

It could be argued that this happened as often as it did, because the juries would have some empathy with the defendant and their economic situation, and would therefore be uneasy about committing a person to death for what may often have been a crime of circumstance. This inevitably led to those charged with stealing sheep to the value of more 
than one shilling being convicted of petty larceny, particularly if they were seen as nonviolent or if it was their first offence (Beattie, 1986).

This situation became particularly pertinent during the eighteenth century when the number of crimes that became non-clergyable now included sheep stealing. Up until this point, those charged with sheep stealing who were shown to be literate could claim benefit of the clergy. This meant that those convicted would not receive the death penalty; rather they would be branded with the letter $\mathrm{T}$ on their thumb and released. Only if that person appeared before the courts again charged with grand larceny would the individual receive the traditional punishment.

The outcome of this flexibility of the punishments imposed was to indicate that the death penalty for property crime, although available, was never intended to be diligently applied, and that although the law throughout this period became much more severe, so the sparing application of the ultimate sanction increased. Indeed, JM Beattie (1986) found that although the death penalty was meted upon murders in almost all cases, the same judges directed an acquittal for almost three quarters of horse thieves and sheep rustlers.

Although traditionally associated with agricultural districts in eastern and southern England, poaching was widespread in the North and the Midlands which were much more industrialised (Osborne \& Winstanley, 2006). It wasn't until a change in society beyond the 1870 's that poaching began to decline. The increase in game preservation to provide sport for the nouveaux riche (Thompson, 2000) led to an increase in artificially raised pheasants, which meant that poachers could no longer always rely on the claim that the birds were wild, and therefore 'fair game'. In addition, the increase in game preservation meant an increase in gamekeepers employed to raise the quarry and to manage the estate for the sport and the sporting classes (Orr, 2003).

Rural life was rarely quiet and sedate. During the 1800s, rural unrest was rife as a result of increased industrialisation and the adverse effect this had on the rural economy. An example of such rural unrest can be seen in 1830, in the form of the "Swing" riots, and again in 1834, with the more successful Tolpuddle Martyrs.

By 1830, a string of unfortunate events had paved the way for several months of serious rural unrest. Poor harvests were experienced from 1827 to 1830 causing high prices but low levels of work. In addition, a number of political upheavals occurred during 1830; the death of King George IV and the accession of the more liberal William IV requiring a General Election in Britain, revolution in France, and the Belgian revolt against Dutch control. Closer to home, election campaigns and local issues enflamed an already difficult situation amongst agricultural workers, including attempts to create a harsher Poor Law, increasing unemployment, the increase of already high cottage rent levels, and a dislike of the social control exercised by Anglican ministers in rural areas (Bloy, undated). 
Whilst the earlier breakup of agricultural land into smaller enclosures had a noticeable adverse effect on the subsequent dispossessed small farmers and labourers, it was further advancements in agricultural efficiency that proved to be that proverbial 'straw that broke the camels' back, in the form of the introduction of the threshing machine by many tenant farmers that would become the focus of anger for many agricultural labourers.

The uprising of the labourers, which was to become known as the 'Swing Riots' began in August 1830 when the first threshing machine was destroyed in Lower Hardres in Kent. By December unrest had spread throughout counties in southern and central England (Hammond \& Hammond, 1912). The behaviour of the authorities only served to increase the tension. Frightened by the seemingly uncontrollable destruction, all misdemeanours from petty theft through to serious crime were met with extreme brutality and force. Poaching, the only alternative in many cases for countrymen with hungry families, soon became an unrelenting battle between enemies; the authorities mishandling the actions of huge numbers of labourers, against the labourers who had to balance feeding their families with the knowledge that capture brought death or relocation of the offenders to places like Austrealia (Bonham-Carter, 1952).

Despite traditionally being seen as a problem faced by counties in southern England and East Anglia, further research has revealed that Swing Riots were far more widespread than originally thought, with unrest occurring in almost every county of England in varying degrees of severity (Beckett \& Cannon, 2002). An indication of the extent of the spread of the riots can be seen in Figure 1. Map one shows riots reported from 1 June-22 October 1830; map two shows the period 23 October-30 November 1830; map three shows the period 1 December 1830-31 March 1831.

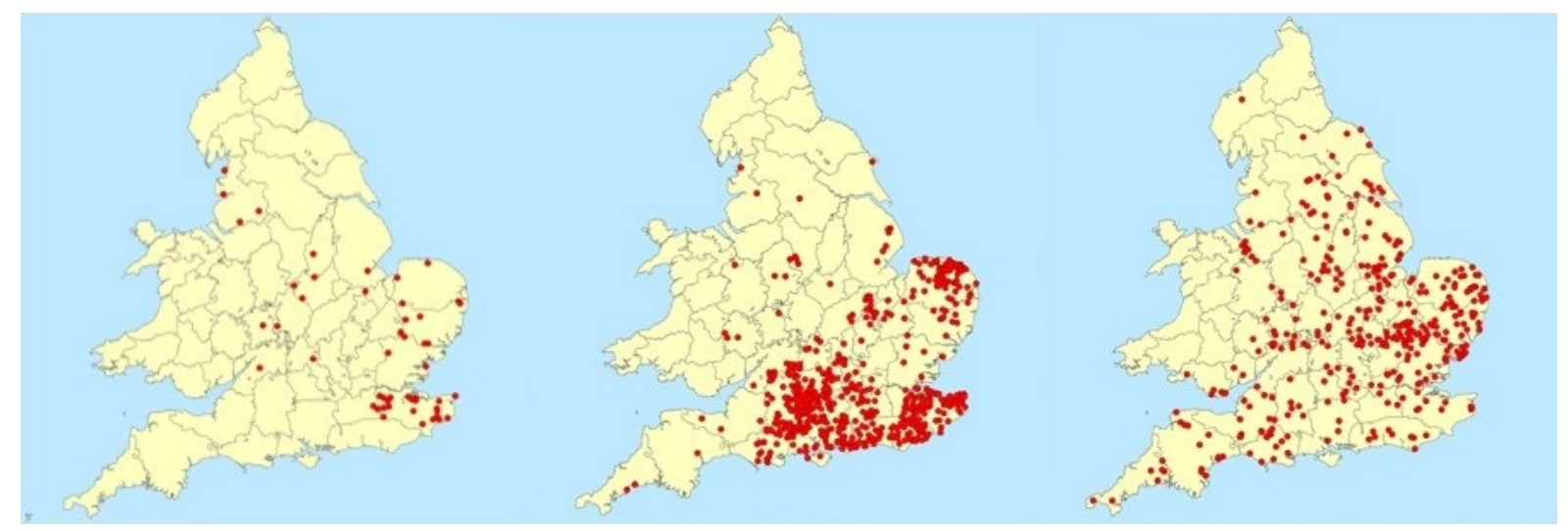

Figure 1: Maps of the spread of the Swing Riots. (Source: Leon, undated)

In addition to the destruction of the threshing machines, these protests took a variety of forms. The rioters sent letters to farmers and manufacturers threatening to destroy their property in an attempt to force them to either remove the machinery or increase the wages paid to the labourers. Such letters were signed by the fictitious 'Captain Swing' from where the term 'Swing Riots' were coined. Haystacks and barns fell victim to arson attacks, and workhouses and overseers were attacked. Despite the extensive destruction and threats that 
were made by the enraged labourers, the principle aims of their protest was simply to secure a minimum living wage and to end rural unemployment (Hobsbawn \& Rudé, 1973).

Westminster were slow to react to the riots, despite the unease caused by the contagious nature of the unrest. Troops were deployed to those areas seen as worst effected, however, in most cases rural magistrates were charged with implementing the law as they saw fit (Anon, 2010). By the end of the troubles, 1976 trials ensued, which saw 19 men executed, 505 transported, 644 imprisoned, and over 800 receiving other, lesser sentences (Robson, 2002).

As a result of the riots, many farmers conceded and raised wages for their labourers. In addition, the church reduced some tithes, and a section of affected landlords reduced rents. But this victory was to be short-lived, with many farmers retracting their agreement to the wage rise. Because of this, for a short period at the beginning of November 1830, the unrest increased again (Charlesworth, 2010). Despite calls for political reform in order to address these disturbances, rural unrest continued unabated throughout the 1830s.

By 1834 conditions for agricultural labourers had not improved, in fact, life in villages like Tolpuddle in Dorset was hard and getting worse with wages already cut from 9 shillings to 7 shillings, with a further cut to 5 shillings expected (Anon, 2000) due to an increased use of machinery in agriculture. As a result, some farm workers resorted to smashing the new threshing machines that had been bought, following in the footsteps of the Swing Rioters. However, this wanton damage was now met with a quick response and a harsh punishment from the courts. As a result, and following the repeal of the Combination Acts which made organisations aimed at gaining better working conditions, and hence Trade Unions, illegal, the men of Tolpuddle established a Friendly Society of Agricultural Labourers. Worried about a repeat of the mass rural unrest seen as a result of the Swing Riots, authorities ordered the arrest of 6 men on charges of unlawful assembly and 'administering unlawful oaths'. This charge came about as members of this Society took a pledge of loyalty which, under the Unlawful Oaths Act 1797 - legislation enacted to deal with a naval mutiny and never repealed - was illegal (Anon, 2000). As a result, the six men were sentenced to 7 years' transportation and working in Australia. The subsequent public uprising to these sentences included a 250,000 name petition and a procession of 30,000 people marching down Whitehall, the centre of government in London, in support of the convicted labourers. After four years of public pressure and a change in Home Secretary, the sentences of the six labourers were quashed and they were given free passage back to England.

In summary, despite the long history of rural crime and rural unrest deserving of academic consideration, rural crime as a research topic is relatively recent. It did not come to the attention of scholars until the 1930s when Sorokin, Zimmerman \& Galpin (1931) devoted a whole chapter of their book 'A Systematic Sourcebook in Rural Sociology Vol. 2' to rural social control; in other words, rural crime. This was soon followed by Wirth's 1938 article entitled 'Urbanism as a way of life' in which social disorganisation theory was introduced, with a distinct urban bias, and by default, an assumption that rural crime was not significant. 
These researchers, along with others conducting research at that time in the United States, were part of the renowned Chicago School of Sociology, a group of sociologists working at the University of Chicago during the first half of twentieth century. The focus of their research was driven by the influx of people moving from surrounding rural areas into the city of Chicago, providing a social laboratory on the doorstep of the University, home of the first department of sociology in America when it was opened in 1872 (Lutters \& Ackerman, 1996).

Despite the work by Sorokin et al (1931) providing a far-reaching study of crime in societies, including an evaluation of crime rates from rural and urban areas of the United States and several European countries, it was the work of scholars associated with the Chicago School of Sociology, including the work of Wirth (1938) on urbanism, that overshadowed rural considerations and laid the path for criminological and sociological research being urban focussed, and this remained the case until the present day.

Similarly, in Britain, the development of criminology as a distinct academic discipline was dominated by urban-centric ideas and scholarship. In contrast to the beginnings of criminological research in America, the British tradition by the 1890s was dominated by psychiatry and medico-legal experts, who in contrast to the anthropological Lombrosian approach supported by European researchers, argued that most offenders did not need psychiatric treatment and should therefore be subject to the normal legal processes (Garland, 2002). This continued until the early part of the twentieth century when European criminology started to move away from its anthropological roots towards an increasingly diverse research agenda. Indeed, it was the appointment of notable European criminology researchers such as Mannheim, Grühunt, and Radzinowicz to leading UK universities that influenced the development of criminology as an independent discipline (Garland, 2002: 45).

In 1931 the Association for the Scientific Treatment of Criminals was founded - later, to be renamed as the Institute for the Scientific Treatment of Delinquency (ISTD) in 1932. The ISTD established Britain's first criminological journal - the British Journal of Delinquency - in 1950, which by 1960 had changed its name to the British Journal of Criminology, and a forum in 1953 called the Scientific Group for the Discussion of Delinquency Problems. However, some members who did not agree with the psychoanalytic focus broke away to creat the more academic-sounding British Society of Criminology. Despite prominent members. Including Grace Pailthorpe and Sigmund Freud, the refusal of the ISTD to move away from its psycholanalytical approach, in part, led to the UK Home Office establishing the Department of Criminal Science at Cambridge University in 1941, which became the foundation for the Cambridge Institute of Criminology established in 1959 with support, and importantly, funding from the Home Office.

It is the introduction of the first postgraduate course training criminology researchers and teachers at the Cambridge Institute of Criminology in 1961 that some herald as the defining event in the emergence of British criminology as an academic discipline (Bowling \& Ross, 2006: 13), establishing the Institute of Criminology’s importance in British 
criminological research. Director of the Cambridge Institute, Leon Radzinowicz, was succeeded by Dr Nigel Walker, who had established the Penal Research Unit - later to become the Centre for Criminology at Oxford - in 1966 (Garland, 2002).

However, despite the important role the Institute of Criminology has played in the development of British criminology as an academic discipline, the fact that this development revolves around the urban universities of London, Cambridge, and Oxford, establishes from the outset the preponderance of the discussion to focus on urban crime issues, which continues and is highlighted by a comment by Bowling \& Ross (2006: 13) who refer to a possible future where "people will call for 'fewer bobbies on the beat"”, which is already a worrying reality in the British countryside.

\section{Myths Surrounding Crime in Rural England}

There are numerous myths surrounding crime in general, but the responses are traditionally from an urban perspective (Bohm and Walker, 2013; Kappeler, Potter and Blumberg, 2005). Existing research has gone some way to identify a number of myths that persist in respect of rural crime (Donnermeyer, Jobes and Barclay, 2006; Barclay, Donnermeyer, Scott and Hogg, 2007). It is argued that there are five myths that are particularly relevant to the situation in England, and it is debateable that whilst these myths persist, any attempt at raising the issue of rural crime in England will continue to be seen as unnecessary by most criminology scholars and policy makers.

\section{Low levels of crime}

The first myth is the idea that rural England experiences low levels of crime. Thanks to UK television programmes such as Heartbeat and The Darling Buds of May, which portrayed rural life as gentle and peaceful, the general public largely retains the idea that rural England is a crime free idyll. But the reality is very different from the myth. Although there are no official datasets to support this, it is purported that, whilst actual numbers of crime might be lower in rural areas, the value of rural crime far exceeds the value of the same number of crimes in urban areas. In addition the impact of rural crimes upon its victims is more significant, as a result of social and geographical isolation, and the financial implications this can have on the victim (National Rural Crime Network, 2015).

A nationwide survey commissioned by the National Rural Crime Network in 2015 has found that the previous estimates of the costs of rural crime have been hugely underestimated. Data provided by the NFU Mutual (2017) Rural Crime Report, based on insurance claims, found that the cost of rural crime in the UK topped £39.2 million. However, the data provided by the National Rural Crime Network survey found from its responses, that crime in rural areas of England and Wales may well be more in the region of £800million (National Rural Crime Network, 2015). But with such disparity, without official statistics or academic research, it is difficult to accurately quantify the true extent of the problem in 
England. It is argued that the difference in these reported data is likely due to the datasets relied upon. The NFU Mutual Report is based on insurance claims for property theft/damage among its own clients. Whereas, the NRCN Survey addressed a much wider audience, and a much wider definition of rural crime, including speeding on rural roads and anti-social behaviour.

\section{Rural Homogeny}

The second myth that persists is that all rural communities are the same, and therefore all rural crimes are the same, and so there is little need for sustained rural criminological research (Donnermeyer et al 2006). This arose as a result of the idea that rural areas can be simplistically defined as areas that are not urban (Statistics NZ, 2006), and as such all rural areas are similar (Buttle, 2006). As a result of this simplistic definition, rural crime came to be defined as “... any incident of crime recorded by police within an area that is classified as non-metropolitan” (Carcach, 2000: 2). Some police forces in England retain a version of this simplistic definition, which perpetuates this myth. As with urban areas, no two rural communities are the same, and so present differing needs for policing and criminological research. In the same vein as urban areas, different crimes can proliferate in different rural areas. This would support the need for an increase in criminological research with a distinct focus on the needs of the rural communities of England and beyond.

\section{Rural is gemeinschaft}

Myth number three is that rural areas of England are equivalent to gemeinschaft, and this perpetuates the rural-urban dichotomy. Ferdinand Tönnies' influential work published in 1887 entitled Gemeinschaft und Gesellschaft was presented as the ideal types of social organisation. It was translated into English as Community and Society in 1955 by Charles Loomis, where gemeinschaft was presented as the "all intimate, private and exclusive living together”, and gesellschaft was the "public life - it is the world itself” (Tönnies, 1887[1955]: 37-38). These title concepts were almost immediately misinterpreted and gemeinschaft came to be characterised by the village and the country town with a focus on the individual, and came to represent and support the idea of the rural idyll; gesellschaft became synonymous with big cities with a focus on the nation. And so sociological and criminological research became and remains urban centric and urban crime was seen as the research priority (DeFlem, 1999).

In reality, the English countryside is no longer private or exclusive (and was not as much as the myth would assume, as the previous discussion showed) as a result of increased mobility, non-farming related businesses carried out on-farm, such as bed and breakfast and farm shops, and an increase in rural tourism in England, all of which invite non-rural residents into the countryside. Despite this, the myth persists within the rural crime discourse in England. As a result, it is argued that this allows the less visible or less attractive aspects of rural life to remain hidden and potentially disregarded by researchers, the police, policy makers, and any other interested parties (Barclay et al, 2007). 


\section{Rural Social Organisation}

Related to this, myth number four purports that rural England is not affected by social disorganisation. The idea claims that as rural areas have low levels of social disorganisation, they do not experience crime as much as urban areas. This is because rural areas are thought to be close knit, with residents having a strong social relationship, and the community has a relatively stable population. It is this supposed stability and high density of acquaintanceship - the idea that everyone knows everyone else, and everyone knows everyone else's business that acts to prevent crime (Bursik and Grasmick, 1993; Sampson and Groves, 1989).

In reality, what is considered social disorganisation is becoming increasingly evident in English villages as a result of the breakdown of the close knit social ties that have been evidence historically. Research shows that this is partly as a result of increasing levels of outmigration, in-migration, and counter-migration in rural areas (Pederson, 2010). With increased mobility, and increasing number of people, particularly young people, are leaving rural areas and moving to cities (Johnson and Fuguitt, 2000), retirees and those looking for a piece of the mythological rural idyll having made their money are moving from the cities to the rural areas (Champion and Watkins, 1991; Costello, 2009), rural residents are moving to other rural areas often to ensure household security, work or for family reasons (Carr and Kefalas, 2009), and people who left rural communities are returning (Farrell, Mahon and McDonagh, 2012; Ni Laoire, 2007). All of this contributes to continued population turnover and other social change that rural areas are experiencing. Furthermore, it is questioned if these changes are actually forms of social disorganization, but instead, are shifting or changing forms of social organization. In other words, rural scholarship on crime is critical of what constitutes social disorganization and its relevance for understanding crime and place, whether that place is large or small (Donnermeyer and DeKeseredy, 2014).

\section{A Recent Phenomenon?}

The fifth and final myth for consideration is the idea that rural crime rates are only now increasing. It is possible that rural crime rates in England have been higher than thought for some time, however, hugely under-reported. As seen in the first section of this paper, rural crime in England can be traced, at least, back to the dissolution of the monasteries in 15361540. The upheaval that came with the reallocation of lands from monasteries to secular landlords resulted in tenant farmer rents being raised, which led to a large number of landless labourers being made unemployed. The numbers of these unemployed labourers increased over time, leading to a moral panic about these 'vagabonds' who became seen as the archetypal early modern rootless criminal described as "idle and suspected persons living suspiciously” (Tomlins and Raithby, 1811: p. 763). It wasn't until 1749 when the precursor of the modern police, the Bow Street Runners, were established, and being tied up with crime in the towns and cities, rural crimes in England were often dealt with locally, often by the landlords. 
Although the Metropolitan Police Force covering the greater London area was created in 1829, its remit was crime occurring in the city of London. It was not until 1839 with the creation of the first of the provincial police forces in accordance with the County Policing Act 1839, that there was any formal policing presence in rural areas. All this history means that rural crime tended to be low on the list of priorities in the early development of the police in England and many other societies.

However, the introduction of the County Policing Act coincided with an analysis of crime statistics in England and Wales carried out by statistician Rawson W. Rawson (1839). He contended that the influence of employment was "very powerful upon their social and moral character" (p. 335). As a result, Rawson undertook a comparison of crime statistics across England and Wales categorised by district: Agricultural Eastern and Southern; Manufacturing Northern and Southern; York; Wales; Mining; Metropolitan Middlesex (London area) and Other Counties.

One of his key conclusions was that crime was predominantly seen in the large towns, and that the proximity of agricultural counties to these urban areas makes them more or less vulnerable to crime. Rawson gives the following example: "Hertfordshire, which is well known to be within reach of the evil influences of the metropolis...proves that its proximity to London is the chief cause of the difference” (p. 339). This is still the position in England today, Hertfordshire included, with people travelling from urban areas for recreational purposes, but then identifying these rural areas as potential targets for criminal activities (Wiles \& Costello, 2000).

Even in 1839, despite rural areas being considered as the quiet countryside, Rawson's analysis indicates that, in many cases, the levels of crime committed in agricultural districts were either on a par, or in excess of those seen in the Metropolitan and Middlesex districts, as indicated by Table 2 below (mining areas excluded from the table).

Rawson argues that the generally higher levels of offences recorded in metropolitan districts is probably due to the presence of a more organised police force in those areas. However, one should question whether, in some cases where levels of offences recorded in agricultural districts are equal to or greater than those in metropolitan districts, that it is as a result of the historical criminalisation of the rural population as a result of the contested crimes and ongoing socio-political unrest within these areas.

By the close of the $20^{\text {th }}$ century and the dawn of the $21^{\text {st }}$ century, technology has meant that it is easier to access information relating to crimes anywhere in the world via the printed press, television news, and latterly the ubiquitous nature of the internet and social media means that reports and conversations relating to rural crime are available to anyone at the touch of a button. However, it must be borne in mind that just because we have more access to these reports, it does not necessarily mean that levels of crimes are increasing beyond where they have been for the last several decades. Rather, we are more exposed to the reports. 
Table 2: Levels of offences in agricultural versus metropolitan districts (Adapted from Rawson, 1839, p. 340)

\begin{tabular}{|c|c|c|c|c|}
\hline Offence & Average & Agricultural & Metropolitan & Middlesex \\
\hline Sexual & \multirow{13}{*}{1.00} & 0.79 & 1.00 & 2.20 \\
\hline $\begin{array}{l}\text { Malicious actions against } \\
\text { property }\end{array}$ & & 1.58 & 1.08 & 0.39 \\
\hline Assault & & 0.77 & 1.31 & 3.51 \\
\hline $\begin{array}{l}\text { Attempts of Maiming \& } \\
\text { murder }\end{array}$ & & 1.11 & 1.11 & 1.31 \\
\hline Manslaughter & & 0.88 & 0.91 & 0.95 \\
\hline Murder & & 1.00 & 1.35 & 0.52 \\
\hline Stealing no violence & & 0.95 & 1.23 & 1.61 \\
\hline Stealing by Fraud & & 0.84 & 1.08 & 1.95 \\
\hline Burglary & & 1.13 & 1.44 & 1.05 \\
\hline Robbery & & 1.19 & 1.14 & 0.97 \\
\hline Poaching & & 1.67 & 0.67 & Nil \\
\hline Coining/Forgery & & 0.64 & 1.33 & 2.94 \\
\hline Riots & & 1.22 & 1.15 & 0.52 \\
\hline
\end{tabular}

\section{Conclusions}

In conclusion, it can be seen that, despite having only been seen in headlines over the past four or five years, rural crime in England has a long and chequered past, dating back to the early modern period in a form that is recognisable today. In addition, it is arguable that the development of rural crime in England has led to a coalescence of rural and urban crime, with the urban having increasing influence and impact upon rural crime. More research is required to address how rural crime has progressed from the local 'socio-political' crimes to become more organised and technologically driven. Such research should consider the changing nature of the crimes seen within the English countryside, and also the people perpetrating these crimes. Consideration should be given to the fact that rural crime no longer reflects the social media driven of a man in a white van with a "travellers" accent (Chetwynd Council, 2017), but rather that rural criminals have evolved in the same way that rural crime has evolved. Are they now business people looking for new opportunities, aided by increased technology, ease of travel, and the persistence of rural crime myths enabling organised crime to expand into the English countryside? 
In many cases, it was the traditional practices of the rural communities that were seen as crimes by the landed gentry and upper classes of English society through the ages, leading to the mass criminalisation of a large part of the population as various times throughout history.

Despite the changing face of rural crime in England, it is possibly the fact that rural crime has such a long history that allows the myths surrounding rural crime to persist as they have become somewhat of a perceived reality. The perpetuation of these myths often means that rural communities have low levels of confidence in the police, rural crime is possibly not always taken seriously, and even worse is hidden by these myths aiming to protect the idea of the rural idyll.

By addressing the myths that continue to surround rural crime in England, and by illustrating that rural crime is not a recent phenomenon that has become an issue in the last few years, it is contended that the need for an increase in rural crime research within English academia is evident and overdue in order to dismantle these myths and reveal the true landscape of crime in the English countryside.

\section{References}

Anderson, N. (1923). The hobo: The sociology of the homeless man. Chicago: Chicago University Press.

Anon. (2010). The Swing Riots of 1830 \& 1831. Retrieved 18/12/2016 from www.swingriotsriotersblacksheepsearch.com/index.php?p=1_6_The_Riots

Anon. (2000). The Tolpuddle Martyrs. Retrieved 17/12/2016 from www.thedorsetpage.com/history/tolpuddle_martyrs/tolpuddle_martyrs.htm

Barclay, E., Donnermeyer, J.F., Scott, J. \& Hogg, R. (2007). Crime in rural Australia. Sydney: Federation Press.

Beattie, J. M. (1986). Crime and the courts in England 1660-1800. Oxford: Oxford University Press.

Beckett, J. \& Cannon, J. (2002). Swing riots. In: J. Cannon. (Ed.) The Oxford Companion to British History 2nd Revised Edition. Oxford: Oxford University Press.

Bernard, G.W. (2011). The dissolution of the monasteries. History, 9(324), 390-409. https://doi.org/10.1111/j.1468-229X.2011.00526.x

Bloy, M. (Undated). Rural Unrest in the 1830s: the "Swing" Riots. Retrieved 05/12/2016 from www.historyhome.co.uk/peel/ruralife/swing.htm 
Bohm, R.M. \& Walker, J. (2013). Demystifying crime and criminal justice (2nd ed.). New York: Oxford University Press.

Bonham-Carter, V. (1952). The English Village (1 ${ }^{\text {st }}$ ed.). London: William Clowes \& Sons Ltd.

Bourn, J. (2002). Agricultural Fraud: The case of Joseph Bowden. Retrieved 14/01/2017 from https://www.nao.org.uk/wp-content/uploads/2002/02/0102615.pdf

Bowling, B. \& Ross, J. (2006). A brief history of criminology. Criminal Justice Matters, 65, 12-13. https://doi.org/10.1080/09627250608553013

Briggs, J., Harrison, C., McInnes, A. \& Vincent, D. (1996.) Crime and punishment in england: An introductory history. London: UCL Press Ltd. https://doi.org/10.1007/978-1-137-08178-0

Burn, R. (1764). The History of the Poor Laws. Retrieved 09/09/2017 from https://books.google.com/books?id=hHUAAAAIAAJ\&oe=UTF-8

Bursik, R.J. \& Grasmick, H.G. (1993). Neighborhoods and crime: The dimensions of effective community control. New York: Lexington Books.

Bushaway, R.W. (1981). "Grovely, grovely and all grovely": Crime and conflict in the English woodland. History Today, 31, 37-43.

Buttle, J.W. (2006). What is known about policing rural crime: reviewing the contemporary literature. Report to the New Zealand Police Rural Liaison.

Byrne, R. \& Smith, K. (2016). Modern Slavery in Agriculture. In J. Donnermeyer (Ed.) The Routledge International Handbook of Rural Criminology (pp. 157-166). London: Routledge.

Carcach, C. (2000). Size, accessibility and crime in regional Australia: Trends and issues in crime and criminal justice. Canberra: Australian Institute of Criminology.

Carr, P.J. \& Kefalas, M.J. (2009). hollowing out the middle: The rural brain drain and what it means for america. Boston: Beacon Press.

Chambliss, W.J. (1964). A sociological analysis of the law of vagrancy. Social Problems, 12, 67-77. https://doi.org/10.2307/798699

Champion, T. \& Watkins, C. (1991). People in the countryside - studies of social change in rural Britain. London: Paul Chapman Publishing. 
Charlesworth, A., Short, B. \& Wells, R. (2010). Riots and unrest. In K. Leslie (Ed.) An Historical Atlas of Sussex. Sussex: Phillimore.

Chetwynd Council (2017). Untitled. Facebook entry dated 24/04/2017 from https://www.facebook.com/profile.php?id=100010006801017

Coleman, D. C. (1956). Industrial growth and industrial revolutions. Economica, 23, 1-22. https://doi.org/10.2307/2551266

Costello, L. (2009). Urban-rural migration: Housing availability and affordability. Australian Geographer, 40; 219-233. https://doi.org/10.1080/00049180902974776

Daelnet (2007). Rural crime concerns aired at national conference. Retrieved on 27/11/2016 from http://www.daelnet.co.uk/countrynews/country_news_15032007.cfm

DeFlem, M. (1999). Ferdinand Tönnies on crime and society: An unexplored contribution to criminological sociology. History of the Human Sciences, 12, 87-116. https://doi.org/10.1177/09526959922120360

Dingwall, G \& Moody, S.R. (1999). Crime and conflict in the countryside. Cardiff: University of Wales Press.

Donnermeyer, J.F., Jobes, P. \& Barclay, E. (2006). Rural crime, poverty, and community. In W.S. DeKeseredy \& B. Perry (Eds.) Advancing Critical Criminology: Theory and Application (pp. 199-218). Lanham, MD: Lexington Books.

Emsley, C. (1987) Crime and society in England 1750-1900. London: Longman.

Farrell, M., Mahon, M. \& McDonagh, J. (2012). The rural as a return migration destination. European Countryside, 4, 31-44. https://doi.org/10.2478/v10091-012-0012-9

Garland (2002). Of crimes and criminals: The development of criminology in Britain. In M. Maguire, R. Morgan, R. Reiner (Eds.) The Oxford Handbook of Criminology $3^{\text {rd }}$ Edition. Oxford: Oxford University Press.

Hammond, J. L. \& Hammond, B. (1912). The village labourer 1760-1832. London: Longman Green \& Co.

Harkness, A., Harris, B. \& Baker, D. (2015). Locating crime in context and place. Sydney: The Federation Press.

Herz, D. C. (2000). Drugs in the Heartland: Methamphetamine use in rural Nebraska. Retrieved 14/01/2017 from https://www.ncjrs.gov/pdffiles1/nij/180986.pdf 
Hobsbawn, E. \& Rude, G. (1973). Captain swing: A social history of the great English agricultural uprising of 1830. New York: W.W. Norton \& Co Ltd.

Hopkins, H. (1985). The long affray: The poaching wars, 1760-1914. London: Secker \& Warburg.

Johnson, K. \& Fuguitt, G. (2000). Continuity and change in rural migration patterns, 19501995. Rural Sociology, 65, 27-49. https://doi.org/10.1111/j.1549-

0831.2000.tb00341.x

Jones, D. J. V. (1979). The poacher: A study in Victorian crime and protest. The Historical Journal, 22(4), 825-860. https://doi.org/10.1017/S0018246X00017143

Jones, M. E. (1939). State police in a rural area. Rural Sociology, 4, 179-189.

Kappeler, V.E., Potter, G.W., \& Blumberg, M. (2005). Mythology of crime and criminal justice, 4th Edition. Illinois: Waveland Press.

Kinney, A. F. (Ed.) (1990). Rogues, vagabonds, \& sturdy beggars: A new gallery of Tudor and early Stuart rogue literature. Amherst: University of Massachusetts Press.

Leon, G. (Undated). Swing riot maps. Retrieved 22/01/2018 from https:/gabrieljleon.wordpress.com/swing-riot-maps/

Lutters, W. G. \& Ackerman, M. S. (1996). An introduction to the Chicago School of sociology. Maryland: University of Maryland Baltimore County.

Main, G. L. (2001). Peoples of a spacious land: Families and cultures in colonial New England. New England: President and Fellows of Harvard College.

Marshall, D. \& Johnson, S. (2005). Crime in Rural Areas: A Review of the Literature for the Rural Evidence Research Centre. London: UCL.

Matsuda, M. (1996) The memory of the modern. Oxford: Oxford University Press.

Mawby, R.I. (2004). Myth and reality in rural policing: Perceptions of the police in a rural county of England. Policing: An international journal of police strategies and management, 27, 431-446. https://doi.org/10.1108/13639510410553158

McLynn, F. (1989). Crime and punishment in eighteenth century England. London: Routledge.

Mingay, G. (1989). The rural idyll. London: Routledge.

Mothershaw, N. (2013). The fraudrReport 2013. Nottingham: Experian. 
National Rural Crime Network (2015). National rural crime survey 2015. Retrieved 18/09/2016 from

http://www.nationalruralcrimenetwork.net/research/internal/national-rural-crimessurvey-2015/

Newton, P. J., Mulcahy, T. M. \& Martin, S. E. (2008). Finding victims of human trafficking. Final report submitted to the National Institute of Justice. Office of Justice Programs, US Department of Justice.

NFU Mutual (2017). Rural crime 2017 - Rural crime now. Retrieved 04/08/2017 from https://www.nfumutual.co.uk/news-and-stories/rural-crime-report-2017/

Ni Laoire, C. (2007). The 'green green grass of home'? Return migration to rural Ireland. Journal of Rural Studies, 23, 332-344. https://doi.org/10.1016/j.jrurstud.2007.01.005

O'Dea, P. J., Murphy, B. \& Balzer, C. (1997). Traffic and illegal production of drugs in Rural America. In: E. B. Robertson, Z. Sloboda, G. M. Boyd, L. Beatty and N. J. Kozel (Eds.) Rural Substance Abuse: State of Knowledge and Issues (pp. 79-89). Rockville, Maryland: National Institute on Drug Abuse.

Orr, W. (1982). Deer Forests, Landlords and Crofters: The Western Highlands in Victorian and Edwardian Times. Edinburgh: John Donald Publishers Ltd.

Osborne, H. \& Winstanley, M. (2006). Rural and urban poaching in Victorian England. Rural History, 17, 187-212. https://doi.org/10.1017/S0956793306001877

Pederson C.J. (2010). Migration, mobility and social disorganization in rural agricultural and recreational communities. MA Thesis, Texas: Baylor University

Quinn, T. (2015). Shooting's strangest days: Extraordinary but true stories from 200 years of shooting. London: Portico.

Rawson, R.W. (1839). An inquiry into the statistics of crime in England and Wales. Journal of the Statistical Society of London, 2, 316-344. https://doi.org/10.2307/2337821

Robson, B. T. (2002). Saviour City: Beneficial effects of urbanization in England and Wales. In I. Douglas, R. Huggett and M. Robinson (Eds.) Companion Encyclopedia of Geography. London: Routledge.

Sampson, R.J. \& Groves, W.B. (1989). Community structure and crime: Testing social disorganisation theory. American Journal of Sociology, 94, 774-802. https://doi.org/10.1086/229068

Sharpe, J.A. (1984). Crime in early modern England, 1550-1750. London: Routledge. 
Sharpe, J. A. (1996). Crime in England: Long-term trends and the problem of modernization. In E. A. Johnson and E. H. Monkkonen (Eds.) The Civilization of Crime: Violence in Town \& Country since the Middle Ages (pp. 17-34). Illinois: University of Illinois Press.

Sorokin, P. I., Zimmerman, C. C. \& Galpin, C. J. (1931). Systematic sourcebook of Rural Sociology, Volume II. Minneapolis: University of Minnesota Press.

Statistics NZ. (2006). New Zealand: An urban/rural profile. Retrieved 15/12/2015 from http://www.stats.govt.nz/browse_for_stats/Maps_and_geography/Geographicareas/urban-rural-profile.aspx

Talbot, E. P. (2011). Human Trafficking: At risk populations in rural communities. Retrieved 17/02/2017 from

http://www.nacsw.org/Publications/Proceedings2011/TalbotEHuman.pdf

Thompson, F. M. L. (2000). Landowners and the rural community. In G. E. Mingay (Ed.) The Victorian Countryside, Volume II. London: Routledge.

Tomlins, T. E. \& Raithby, J. (1811). The statutes at large, of England and of Great Britain: From Magna Carta to the union of the kingdoms of Great Britain and Ireland in Twenty Volumes: Volume II. London: Eyre \& Stratham.

Tonnies, F. (1887)[1955]. Community and society: Gemeinschaft und Gesellschaft (translated by Charles P. Loomis). East Lansing: Michigan State University Press.

Wiles, P. \& Costello, A. (2000). The 'Road to nowhere': The evidence for travelling criminals. Home Office Briefing Note 04/00. Retrieved 11/09/2017 from http://www.popcenter.org/tools/offender_interviews/PDFs/WilesCostello.pdf

Wirth, L. (1938). Urbanism as a way of life. American Journal of Sociology, 40, 1-24. https://doi.org/10.1086/217913

Wooff, A. (2015). Relationships and responses: Policing anti-social behaviour in rural Scotland. Journal of Rural Studies, 39, 287-295. https://doi.org/10.1016/j.jrurstud.2014.11.003 